\title{
IMPLEMENTASI ALGORITMA COMPLEMENTARY FILTER UNTUK MERANCANG BANGUN INTERAKSI MANUSIA DAN SMARTPHONE MENGGUNAKAN GERAKAN KEPALA
}

\author{
Pingky Alfa Ray Leo Lede ${ }^{1 \otimes}$

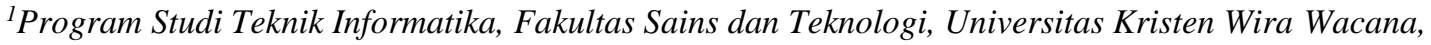 \\ Sumba \\ $\square_{e-m a i l}$ : pingky.leo.lede@unkriswina.ac.id
}

\begin{abstract}
This study proposes an approach to design and build interaction systems for smartphone's users with hand disabilities using the user's head movements through the implementation of the fusion complementary filter algorithm to get the angle of orientation and position of user's head. The main objective of this experimental research is to get the best constant function of complementary filters that have the highest accuracy result. The results of this study indicate that the fusion complementary filter algorithm can be used to measure the angle of the user's head movements using a combination of 3 sensors; namely the accelerometer, gyroscope and magnetometer, with the best constants function are 0.99 for the gyroscope and 0.01 for the accelerometer. Complementary filter performance results using fusion of 3 sensors to measure the user's head angle obtained from the calculation of the root mean squared error (RMSE) with an average value of 0.364 on the $x$-axis (roll), 0.578 on the y-axis (pitch), and 0.767 on the z-axis (yaw).
\end{abstract}

Keywords: Complementary Filter, Fusion Algorithm, Human-Smartphone Interaction, Smart Machine

\begin{abstract}
Abstrak
Penelitian ini mengusulkan sebuah pendekatan untuk membangun sistem interaksi bagi para pengguna cacat tangan menggunakan gerakan kepala penggunanya melalui implementasi algoritma fusion sensor complementary filter untuk mendapatkan orientasi sudut serta posisi kepala dari penggunanya. Penelitian ini bersifat eksperimental dengan tujuan utama untuk mendapatkan fungsi alih terbaik pada complementary filter yang memiliki nilai akurasi tertinggi. Hasil dari penelitian ini menunjukkan bahwa algoritma fusion complementary filter dapat digunakan untuk mengukur sudut dari gerakan kepala pengguna menggunakan gabungan 3 buah sensor; yaitu accelerometer, gyroscope dan magnetometer, dengan konstanta fungsi alih terbaik bernilai 0,99 untuk gyroscope dan 0,01 untuk accelerometer. Hasil kinerja complementary filter menggunakan fusion ketiga sensor untuk mengukur sudut kepala pengguna didapatkan dari perhitungan root mean squared error (RMSE) dengan nilai rata-rata 0,364 pada sumbu putar $x$ (roll), 0,578 pada poros sumbu $y$ (pitch), dan 0,767 pada poros sumbu $z$ (yaw).
\end{abstract}

Kata kunci: Algoritma Fusion, ComplementaryFilter, Interaksi Manusia dan Smarphone, Mesin Cerdas

\section{Pendahuluan}

Banyak pendekatan yang telah dilakukan untuk mengatasi kelemahan sistem interaksi smartphone bagi para pengguna cacat tangan, antara lain: Pemanfaatan pengolahan citra digital untuk meningkatkan pengalaman interaksi bagi pengguna cacat tangan [1]. Pengolahan citra digital yang dimaksud adalah dengan menggunakan kamera depan telepon genggam yang sudah ditambahkan dengan lensa lebar untuk melakukan pemrosesan citra yang lebih luas cakupannya. Penelitian tersebut menunjukkan bahwa penggunaan kamera depan telepon genggam untuk konteks perhitungan 3 dimensi cukup sulit dilakukan hanya dengan 1 kamera, selain itu pada aspek kehandalan, pengolahan citra digital menjadi berkurang kinerjanya pada saat iluminasi 
yang cukup buruk, hal tersebut disebabkan karena banyak derau yang dihasilkan pada saat kondisi kurang cahaya.

Sistem komunikasi antara sensor inersia dan smartphone dapat dibangun menggunakan teknologi jaringan bluetooth [2] dimana jalur komunikasi dengan tongue driver system (TDS) adalah komunikasi bluetooth dengan lidah yang digunakan sebagai penggerak kursor pada smartphone. Penelitian yang lain juga menunjukkan bahwa proses interaksi antara pengguna cacat tangan juga dapat dikembangkan menggunakan sensor inersia untuk mendukung antarmuka bagi pengguna cacat tangan dengan mesin. Interaksinya dibangun dari pelacakan lengan menggunakan sensor inersia yang dipakai pada lengan dari pengguna smartphone [3]. Pada penelitian tersebut para peneliti mengembangkan metode fusion untuk mengkompensasi drift pada fusion accelerometer dan gyroscope menggunakan magnetometer. Kompensasi tersebut lalu dievaluasi menggunakan root mean squad error (RMSE) dengan hasil perhitunganya adalah sebesar $2,9^{\circ}$.

Penelitian yang dilakukan untuk mengembangkan sistem antaramuka pengguna dengan smartphone juga dilakukan dengan menempatkan 3 elektroda secara noninvasive pada wajah pengguna smartphone untuk mendapatkan gerakan kedipan mata sebagai perintah dalam berinteraksi dengan smartphone [4]. Penelitian ini menggunakan OpenBCI untuk proses pengolahan sinyal yang dikoneksikan dengan laptop melalui jalur komunikasi Bluetooth, sinyal tersebut kemudian diekstrak dan diterjemahkan menjadi perintah yang dikirim melalui jalur komunikasi Wi-Fi menuju smartphone.

Terkait gerakan kepala, telah dilakukan penelitian low-cost MEMS sensor pada Oculus Rift untuk mengatasi reckoning error menggunakan gravitasi dan bidang magnetik pada proses pelacakan gerakan kepala [5]. Penelitian tersebut menunjukan bahwa gerakan kepala dapat dilacak menggunakan sensor-sensor pengukuran inersia, salah satunya adalah menggunakan sensor-sensor yang ditempatkan pada Oculus Rift. Oculus Rift merupakan salah satu alat pelacakan kepala yang memiliki tingkat akurasi yang tinggi, tetapi dari sisi harga alat tersebut cukup mahal untuk dijangkau oleh para pengguna smartphone oleh karena itu Oculus Rift sering digunakan untuk fungsi entertaining dan gaming. Pada penelitian ini, prinsip kerja yang sama dari pelacakan gerakan kepala pengguna smartphone menggunakan sensor inersia pada Oculus Rift, dapat digunakan untuk proses pelacakan kepala dari pengguna smartphone.

Selain itu, untuk mengukur kinerja hasil perhitungan algoritma fusion complementary filter dapat menggunakan persamaan root mean square error (RMSE) seperti yang telah dilakukan pada penelitian sebelumnya [6] untuk menghitung hasil kompensasi drift pada algoritma fusion yang diterapkan dalam melacak gerakan lengan pengguna untuk mengembangkan sistem interaksi mesin dan manusia.

Perhitungan nilai sudut dari gerakan kepala dapat dilakukan dengan pendekatan yang sama yang telah dilakukan pada penelitian sebelumnya, yaitu menggunakan salah satu anggota tubuh sebagai poros untuk menghasilkan interaksi [7]. Pada penelitian tersebut, pelacakan gerakan kepala ditujukan untuk membangun sistem interaksi antara manusia dengan komputer menggunakan pengolahan citra digital dengan cara mengekstraksi ciri wajah sehingga mendapatkan posisi mulut sebagai penentu gerakan kursor dan perintah pada mouse. 
Berdasarkan penjelasan latar belakang penelitian yang telah dijabarkan sebelumnya, dapat disimpulkan bahwa masih dibutuhkan pengembangan sistem antar muka untuk meningkatkan interaksi antara pengguna cacat dengan smartphone, oleh karena itu tujuan dari penelitian ini adalah menerapkan algoritma fusion complementary filter pada sensor-sensor inersia untuk mendapatkan gerakan kepala pengguna yang nantinya dapat digunakan sebagai landasan untuk melakukan rancang bangun sistem interaksi antara pengguna dan smartphone. Penelitian ini juga bertujuan untuk menentukan nilai konstanta fungsi alih dengan performa terbaik dalam proses pengukuran serta menampilkan hasil evaluasi kinerja dari algoritma fusion compelementry filter pada gerakan kepala pengguna cacat tangan.

\section{Metode Penelitian}

Terdapat beberapa metode penelitian yang digunakan pada penelitian ini, antara lain: (1) Kajian literasi dan (2) Uji coba alat; dimana proses pengujian dilakukan secara eksperimental pada 5 sudut istimewa $\left(0^{\circ}, 30^{\circ}, 45^{\circ}, 60^{\circ}\right.$, dan $90^{\circ}$ ), yaitu dengan menggerakan alat sesuai dengan poros sumbu yang diukur. Data ukur yang diambil adalah hasil rerata dari 100 data pengukuran pada setiap poros sumbu pengukuran, kemudian hasil pengukuran tersebut dievaluasi nilai galatnya menggunakan persamaan RMSE untuk menentukan kinerja complementary filter pada saat pengukuran.

\section{Inertial Measurement Unit}

Inertial Measurement Unit atau yang biasa disingkat dengan IMU merupakan sebuah modul sensor yang digunakan untuk melakukan pengukuran inersia yang dialaminya; baik tentang kecepatan, gaya gravitasi juga orientasi yang dialami oleh modul sensor tersebut. Pengukuran yang dilakukan merupakan hasil kombinasi dari beberapa sensor, antara lain accelerometer, gyroscope dan terkadang juga menggunakan magnetometer.

\section{Accelerometer}

Accelerometer merupakan sebuah inertial sensor yang mampu mengukur besar dan arah dari percepatan sebuah benda yang melekat padanya. Percepatan yang terukur berupa percepatan statis akibat gaya gravitasi bumi dan percepatan dinamis akibat pergerakan maupun getaran yang dialami accelerometer. Sebagai contoh, sebuah modul ADC 10-bit akan menghasilkan nilai dengan antara $0 . .1023$, hasil tersebut didapatkan dari $1023=210-1$. Sedangkan sebuah modul ADC 12-bit akan menghasilkan nilai dalam rentangan $0 . .4095$, yang berasal dari 212-1. Representasi model X, Y, dan Z pada accelerometer dapat dilihat pada Gambar 1.

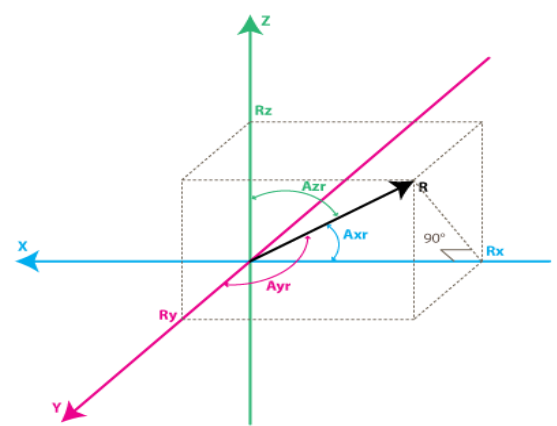

Gambar 1. Representasi model X, Y, dan Z pada accelerometer

Untuk mendapatkan nilai sudut dari sebuah accelerometer maka dapat dilakukan perhitungan sebagai berikut

$$
\cos (\mathrm{Axr})=\frac{\mathrm{Rx}}{\mathrm{R}}
$$




$$
\begin{aligned}
& \cos (A y r)=\frac{R y}{R} \\
& \cos (A z r)=\frac{R z}{R}
\end{aligned}
$$

Nilai R didapatkan dari persamaan

$$
\mathrm{R}=\sqrt{\mathrm{Rx}^{2}+\mathrm{Ry^{2 } + R z ^ { 2 }}}
$$

Dari persamaan tersebut, dapat dilakukan perhitungan untuk mencari nilai sudut menggunakan persamaan berikut (fungsi arccos adalah fungsi invers dari fungsi cosinus)

$$
\begin{aligned}
& A x r=\arccos \frac{R x}{R} \\
& A y r=\arccos \frac{R y}{R} \\
& A z r=\arccos \frac{R z}{R}
\end{aligned}
$$

Ketiga persamaan tersebut dapat juga dirumuskan sebagai berikut

$$
\begin{aligned}
& \cos X=\cos (A x r)=\frac{R x}{R} \\
& \cos Y=\cos (A y r)=\frac{R y}{R} \\
& \cos Z=\cos (A z r)=\frac{R z}{R}
\end{aligned}
$$

Ketiga persamaan tersebut disebut dengan direction cosine, dan pada dasarnya persamaan tersebut merepresentasikan unit vektor (vektor dengan panjang 1) yang memiliki arah yang sama dengan vektor R. Nilai tersebut dapat diverifikasikan menggunakan persamaan berikut

$$
\sqrt{\operatorname{Cos} x^{2}+\operatorname{Cos} y^{2}+\operatorname{Cos} z^{2}}=1
$$

\section{Gyroscope}

Gyroscope akan mengukur kecepatan perubahan sudut sesuai dengan yang telah didefinisikan sebelumnya, dengan kata lain hasil pengukuran tersebut secara linear berhubungan dengan kecepatan sudut dari sudut-sudut tersebut. Representasi model dari gyroscope dapat dilihat pada Gambar 2.

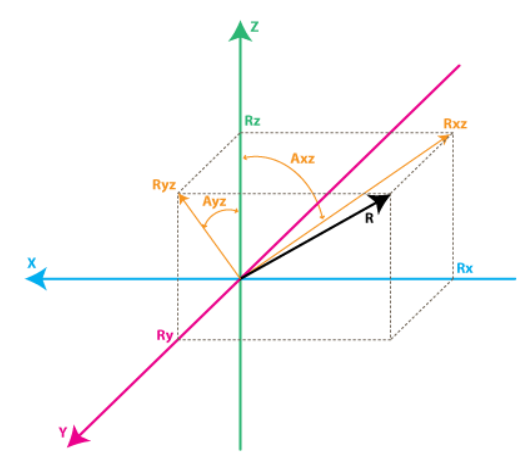

Gambar 2. Representasi model gyroscope

Setiap channel gyroscope mengukur rotasi dari sebuah axis. Sebagai contoh 2 axis yang akan diukur rotasinya oleh gyroscope adalah rotasi antara axis $\mathrm{X}$ dan Y. Untuk menampilkan nilai rotasi dapat dilakukan melalui beberapa persamaan, namun sebelumnya dapat didefinisikan

- Rxz - adalah proyeksi dari tekanan inersia vektor $\mathrm{R}$ pada sumbu XZ

- Ryz - adalah proyeksi dari tekanan inersia vektor $\mathrm{R}$ pada sumbu $\mathrm{YZ}$

Menggunakan teorema pythagoras dari sudut kanan segitiga yang dibentuk dari $\mathrm{Rxz}$ dan $\mathrm{Rz}$ dapat dihasilkan persamaan berikut

$$
\begin{aligned}
& \mathrm{Rxz}^{2}=\mathrm{Rx^{2 }}+\mathrm{Rz}^{2} \\
& \mathrm{Ryz} \mathrm{z}^{2}=\mathrm{Ry}^{2}+\mathrm{Rz} \mathrm{z}^{2}
\end{aligned}
$$

Dari sudut kanan segitiga yang terbentuk dari $\mathrm{R}$ dan Ryz maka dapat dihasilkan persamaan berikut

$$
\begin{aligned}
& \mathrm{R}^{2}=\mathrm{Rx} z^{2}+\mathrm{Ry}^{2} \\
& \mathrm{R}^{2}=\mathrm{Ryz} z^{2}+\mathrm{Rx}^{2}
\end{aligned}
$$


Definisi sudut antara axis $\mathrm{Z}$ dan vektor Rxz, Ryz adalah sebagai berikut

- Axz - adalah sudut antara Rxz (proyeksi dari $\mathrm{R}$ pada sumbu $\mathrm{XZ}$ ) dan axis $\mathrm{Z}$

- Ayz - adalah sudut antara Ryz (proyeksi dari R pada sumbu YZ) dan axis Z

Sebagai contoh, dapat diasumsikan bahwa pengukuran sudur rotasi pada axis $\mathrm{Y}$ telah dilakukan (sudut $\mathrm{Axz}$ ) pada $\mathrm{t}_{0}$, yang didefinisikan sebagai $\mathrm{Axz}_{0}$, kemudian dilakukan pengukuran pada waktu selanjutnya $\mathrm{t}_{1}$ dan didefinisikan sebagai $\mathrm{Axz}_{1}$. Kecepatan perubahan dapat dihitung menggunakan persamaan berikut ini

$$
\text { Rate } A x z=\frac{\left(A x z_{1}-A x z_{0}\right)}{\left(t_{1}-t_{0}\right)}
$$

Jika Axz adalah dalam bentuk derajat dan $\mathrm{t}$ adalah waktu dalam satuan detik, maka hasil pengukuran gyroscope adalah derajat/detik.

\section{Sudut Euler}

Sudut Euler merepresentasikan urutan tiga elemen rotasi, seperti axis rotasi suatu sistem koordinat. Sebagai contoh, axis pertama pada rotasi adalah $\mathrm{Z}$ dengan sudut $\alpha$, axis kedua pada rotasi adalah $X$ dengan sudut $\beta$, axis terakhir pada rotasi adalah $\mathrm{Y}$ dengan sudut $\gamma$. Rotasi ini dimulai dari sebuah standar orientasi yang diketahui. Setiap orientasi bisa didapatkan dari susunan ketiga elemen rotasi.

Sudut euler pada pada sebuah objek yang berotasi dapat dijelaskan dengan mengasumsikan sebuah objek B yang memiliki koordinat lokal Oxyz memiliki posisi yang bertepatan dengan frame koordinat global OXYZ seperti pada Gambar 3.

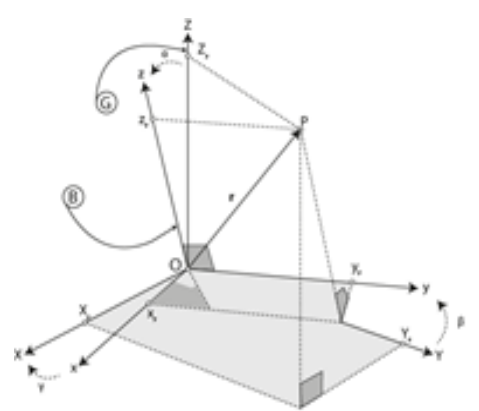

Gambar 3. Rotasi objek B pada global frame $\mathrm{G}$ dengan titik pusat $\mathrm{O}$

Titik O pada objek B memiliki posisi tetap pada frame $\mathrm{G}$ yang juga merupakan titik asal dari kedua frame. Rotasi pada sumbu $\mathrm{X}$ dalam sebuah frame koordinat global disebut roll, rotasi pada sumbu Y dalam sebuah frame koordinat global disebut pitch, sedangkan rotasi pada sumbu $\mathrm{Z}$ pada sebuah frame koordinat global disebut yaw. Gambar 4 mengilustrasikan rotasi 45 derajat roll, pitch, dan yaw pada frame koordinat global.

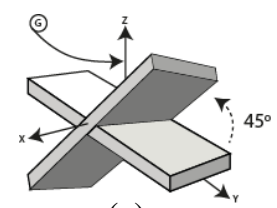

(a)

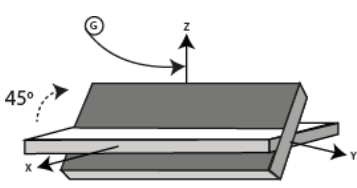

(b)

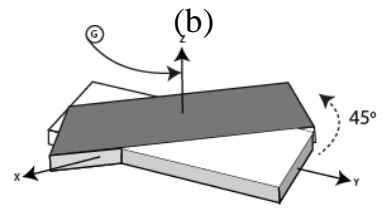

(c)

Gambar 4. Rotasi global roll (a), pitch (b), dan yaw (c)

\section{Sensor fusion}

Sensor fusion dapat didefinisikan sebagai teori, teknik maupun tools yang digunakan untuk mengkombinasikan data sensor, atau data yang berasal dari 
data sensorik ke dalam format representasi umum. Tujuan dari sensor fusion sendiri adalah untuk meningkatkan kualitas informasi yang dihasilkan.

Multi-sensor data fusion dapat meningkatkan kinerja sistem dalam 4 cara, antara lain: (1) Representasi, Informasi yang dihasilkan baik pada saat berlangsung, atau pada akhir dari proses fusion memiliki level abstraksi dan granualitas yang lebih tinggi dibandingkan masing-masing data set input. Level abstraksi yang baru atau granualitas yang baru menyediakan nilai semantik yang lebih kaya akan data dibandingkan dengan setiap inisial sumber informasi; (2) Nilai kepastian (certainty), Jika $\mathrm{V}$ adalah sensor data sebelum fusion dan $\mathrm{p}(\mathrm{V})$ adalah probabilitas priori data sebelum fusion, maka kelebihannya untuk nilai kepastian adalah meningkatnya $\mathrm{p}(\mathrm{V})$ setelah proses fusion. Jika Vf melambangkan data setelah fusion, maka dapat diharapkan bahwa $\mathrm{p}(\mathrm{Vf})>\mathrm{p}(\mathrm{V})$; (3) Akurasi (accuracy), Standar deviasi pada data setelah proses fusion lebih kecil dibandingkan nilai standar deviasi yang disediakan langsung dari sumbernya. Jika data memiliki noise dan error, maka proses fusion akan berusaha untuk mengurangi ataupun mengeliminasi noise dan error tersebut. Pada umumnya, peningkatan dalam akurasi dan nilai kepastian adalah saling berkaitan; (4) Completeness, Membawakan informasi yang baru kepada pengetahuan yang sekarang tentang sebuah lingkungan yang memampukan untuk melihat secara lebih utuh dalam lingkungan tersebut. Pada umumnya, jika informasi bersifat redudant dan konkordan, maka dapat meningkatkan nilai akurasinya.

\section{Complementary filter}

Complementary filter adalah salah satu algoritma sensor fusion yang mana sesuai dengan namanya, filter tersebut menggabungkan 2 jenis input berbeda yaitu dari sensor gyroscope dan accelerometer yang diproses sehingga mendapatkan nilai output dari filter tersebut. Penggabungan tersebut dimaksudkan untuk mengatasi kelemahan accelerometer dan gyroscope sehingga mendapatkan pengukuran yang lebih akurat.

Sensor accelerometer dapat memberikan nilai sudut kemiringan yang akurat ketika sistem dalam keadaan diam (statis), namun keakurasian berkurang ketika sistem sedang dalam keadaan bergerak (dinamis). Hal ini dikarenakan sensor accelerometer tidak mampu mengikuti pergerakan yang cepat karena memiliki respon lambat dan juga memiliki derau dalam melakukan pengukuran. Sedangkan gyroscope dapat memberikan nilai sudut kemiringan dalam keadaan bergerak (dinamis) namun menjadi tidak akurat dalam keadaan jangka panjang dikarenakan adanya efek bias (drift) yang dihasilkan oleh gyroscope. Secara umum, persamaan yang berlaku pada algoritma complementary filter adalah

Sudut $=(0.98) \times($ sudut + NilaiGyroscope $\times \mathrm{dt})$ $+(0.02) \times$ NilaiAccelerometer

Complementary filter juga adalah sebuah filter yang menggunakan 2 atau lebih fungsi alih yang jika dijumlahkan akan menghasilkan fungsi alih dengan nilai 1 . Pengertian fungsi alih disini adalah proporsi perbandingan besarnya presentase nilai accelerometer dan presentase nilai gyroscope yang digunakan pada proses sensor fusion yang jika dijumlahkan presentase tersebut bernilai $100 \%$. Prinsip kerja dari complementary filter adalah dengan menggabungkan nilai sudut sekaligus 
untuk menghilangkan derau. Sinyal masukan pertama yaitu sudut hasil pengukuran oleh accelerometer memiliki derau pada frekuensi tinggi sehingga difilter menggunakan low-pass filter. Sinyal masukan kedua yaitu kecepatan sudut hasil pengukuran oleh gyroscope memiliki derau pada frekuensi rendah sehingga di-filter dengan high-pass filter. Nilai 0,98 pada persamaan di atas adalah nilai konstanta untuk high-pass filter yang terdapat dalam sensor gyroscope, sedangkan nilai 0,02 adalah nilai konstanta dari low-pass filter yang terdapat dalam sensor accelerometer. Dan jika nilai 0,98 dan nilai 0,02 dijumlahkan maka akan menghasilkan nilai 1, dimana mengilustrasikan algoritma complementary filter. Skema algoritma complementary filter dapat dilihat pada Gambar 5.

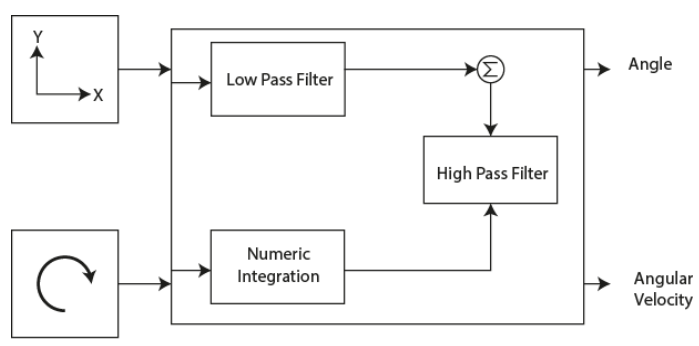

Gambar 5. Skema algoritma complementary filter [8]

\section{Hasil Dan Pembahasan}

\section{Hasil Pengukuran Sudut Euler Menggunakan Complementary Filter}

Pengujian ini dilakukan untuk mengkompensasi drift hasil pengukuran dari gyroscope dan derau mekanik yang diukur oleh accelerometer. Prinsip utama complementary filter adalah dengan melakukan high-pass filter pada hasil pengukuran sudut oleh gyroscope dan low-pass filter pada hasil pengukuran sudut dari accelerometer. Nilai konstanta complementary filter yang digunakan adalah 0,99 pada gyroscope dan 0,01 pada accelerometer. Hasil pengukuran sudut euler menggunakan complementary filter dapat dilihat pada Gambar 6.

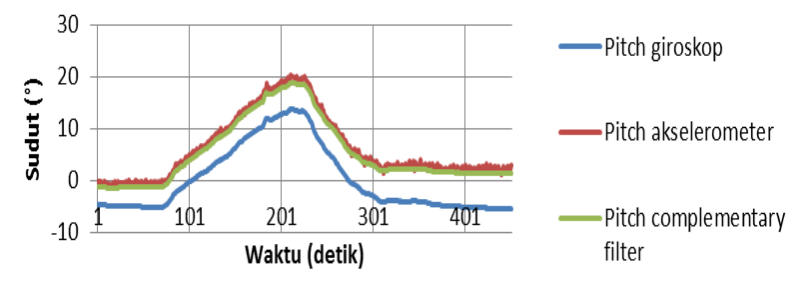

(a)

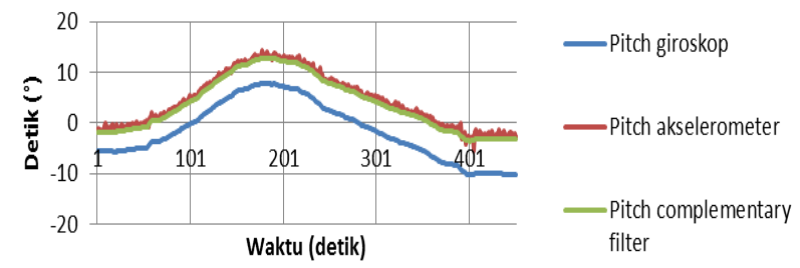

(b)

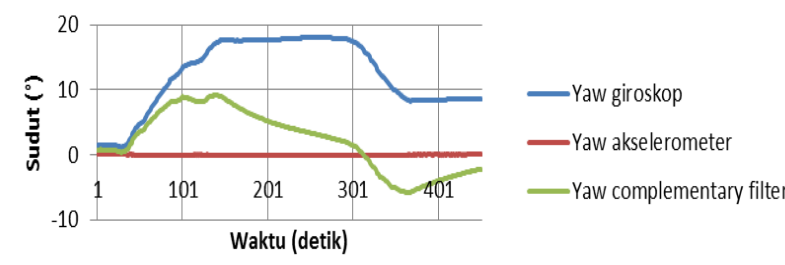

(c)

Gambar 6. Perbandingan hasil pengukuran sudut pitch (a), roll (b) dan yaw (c) dengan dan tanpa menggunakan complementary filter

Hasil pengujian aloritma fusion complementary filter menunjukan grafik hasil ukur yang lebih halus serta tidak memiliki drift pada pengukuran 2 sumbu poros, yaitu pada sudut pitch dan roll, sedangkan pada sudut yaw, masih terjadi ketidak akuratan hasil pengukuran ketika diberikan sudut putar tertentu pada sumbu Z. Gambar 6 (c) menunjukan error drift masih terjadi pada hasil pengukuran, oleh karena itu untuk mengkompensasi error drift pada sumbu yaw perlu dilakukan pengujian complementary filter menggunakan hasil pengukuran pada sensor lain; yang memiliki referensi ukur sudut selain dari gaya gravitasi bumi pada poros sumbu putar Z, yaitu magnetometer. 
Hasil Pengukuran Sudut Yaw Menggunakan Complementary Filter pada Poros Sumbu Putar Z Magnetomer

Hasil pengujian sebelumnya menunjukan bahwa hasil pengukuran pada sudut yaw masih mengalami error drift, hal ini disebabkan karena accelerometer tidak mampu melakukan pengukuran pada sumbu yang tegak lurus terhadap gaya gravitasi bumi, karena tidak adanya gaya yang bekerja pada sumbu-sumbu tersebut. Selain itu, hasil pengujian sebelumnya juga menunjukan hasil pengukuran oleh gyroscope pada sudut yaw yang masih mengalami error drift, oleh karena itu pengujian ini dilakukan untuk mengetahui apakah dengan menggunakan hasil pengukuran magnetometer pada poros sumbu $\mathrm{Z}$ dapat mengatasi error drift yang terjadi pada sudut yaw.

Hasil pengujian complementary filter menggunakan hasil pengukuran magnetometer pada poros sumbu putar $\mathrm{Z}$ untuk mendapatkan nilai sudut yaw dapat dilihat pada gambar 7 .

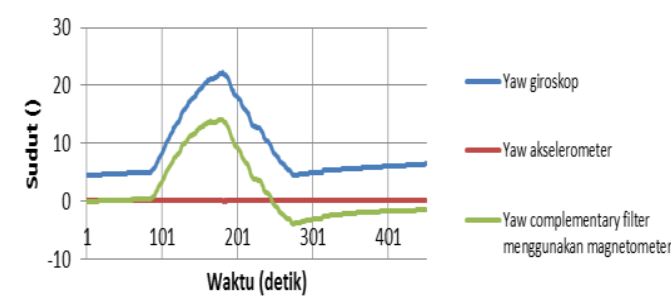

Gambar 7. Hasil pengukuran sudut yaw menggunakan complementary filter pada poros sumbu putar Z

Grafik hasil pengujian complementary filter menunjukkan bahwa error drift pada sumbu yaw berhasil terkompensasi, oleh karena itu untuk pengukuran sudut yaw, algoritma complementary filter yang akan digunakan pada sistem navigasi adalah sebagai berikut

$$
\psi_{\text {comp }}=\mathrm{K} \psi_{\text {gyro }}+(1-\mathrm{K}) \psi_{\text {magnet }}
$$

Dimana,

$\psi_{\text {comp }}=$ Hasil perhitungan sudut menggunakan complementary filter

$\mathrm{K}=$ Konstanta complementary filter $\psi_{\text {gyro }}=$ Hasil perhitungan sudut pada poros sumbu putar $\mathrm{Z}$ gyroscope $\psi_{\text {magnet }}=$ Hasil perhitungan sudut pada poros sumbu putar $\mathrm{Z}$ magnetometer

Setelah error drift hasil pengukuran pada sudut yaw berhasil didapatkan, maka dapat dilakukan pengukuran kinerja complementary filter pada ketiga poros sumbu putar. Hasil evaluasi kinerja complementary filter pada pengukuran masing-masing sumbu poros dapat dilihat pada Tabel 1, Tabel 2 dan Tabel 3.

Tabel 1. Hasil pengukuran complementary filter pada poros sumbu putar X

\begin{tabular}{cccc}
\hline & $\begin{array}{c}\text { Sudut } \\
\text { Sebenarnya } \\
\text { No } \\
\text { yang } \\
\text { diukur } \\
\text { dengan } \\
\text { busur }\left(^{\circ}\right)\end{array}$ & $\begin{array}{c}\text { Sudut yang } \\
\text { terukur }\left(^{\circ}\right) \\
\text { dari rata- } \\
\text { rata 100 } \\
\text { data } \\
\text { pengukuran }\end{array}$ & RMSE \\
\hline 1 & 0 & 0,058 & 0,003 \\
2 & 30 & 3,915 & 1,019 \\
3 & 45 & 45,508 & 0,258 \\
4 & 60 & 60,453 & 0,227 \\
5 & 90 & 90,481 & 0,313 \\
\hline \multicolumn{4}{c}{0,364} \\
\hline \multicolumn{4}{c}{ Rata-rata }
\end{tabular}

Tabel 2. Hasil pengukuran complementary filter pada poros sumbu putar Y

\begin{tabular}{cccc}
\multicolumn{4}{c}{ pada poros sumbu putar Y } \\
\hline $\begin{array}{c}\text { Sudut } \\
\text { sebenarnya } \\
\text { yang diukur } \\
\text { dengan } \\
\text { busur }\left(^{\circ}\right)\end{array}$ & $\begin{array}{c}\text { Sudut yang } \\
\text { terukur }\left(^{\circ}\right) \\
\text { dari rata- } \\
\text { rata 100 } \\
\text { data } \\
\text { pengukuran }\end{array}$ & RMSE \\
\hline 1 & 0 & 0,512 & 0,542 \\
2 & 30 & 30,441 & 0,443 \\
3 & 45 & 45,067 & 0,209 \\
4 & 60 & 61,207 & 1,265 \\
5 & 90 & 90,417 & 0,432 \\
\hline \multicolumn{4}{c}{ Rata-rata } \\
\hline \multicolumn{3}{c}{}
\end{tabular}


Tabel 3. Hasil pengukuran complementary filter pada poros sumbu putar Z

\begin{tabular}{cccc}
\multicolumn{4}{c}{ pada poros sumbu putar Z } \\
\hline $\begin{array}{c}\text { Sudut } \\
\text { sebenarnya } \\
\text { yang diukur } \\
\text { dengan } \\
\text { busur }\left({ }^{\circ}\right)\end{array}$ & $\begin{array}{c}\text { Sudut yang } \\
\text { terukur }\left(^{\circ}\right) \\
\text { dari rata- } \\
\text { rata 100 } \\
\text { data } \\
\text { pengukuran }\end{array}$ & RMSE \\
\hline 1 & 0 & 0,814 & 0,814 \\
2 & 30 & 31,024 & 1,061 \\
3 & 45 & 46,285 & 1,285 \\
4 & 60 & 59,916 & 0,083 \\
5 & 90 & 90,591 & 0,592 \\
\hline \multicolumn{4}{c}{ Rata-rata } \\
\hline \multicolumn{3}{c}{}
\end{tabular}

Berdasarkan data tersebut disimpulkan bahwa nilai rata-rata RMSE yang dihasilkan menggunakan complementary filter pada poros sumbu $\mathrm{X}$ adalah $0,364^{\circ}$, pada poros sumbu $\mathrm{Y}$ adalah $0,578^{\circ}$ dan pada poros sumbu $\mathrm{Z}$ adalah $0,767^{\circ}$.

\section{Kesimpulan}

Berdasarkan hasil penelitian yang telah dilakukan, maka dapat disimpulkan: (1) Penggunaan algoritma fusion complementary filter untuk melakukan perhitungan orientasi serta posisi gerakan kepala berhasil dilakukan dengan konstanta fungsi alih yang terbaik adalah 0,99 pada accelerometer dan 0,01 pada gyroscope;

Accelerometer tidak dapat melakukan pengukuran untuk sudut yaw dikarenakan karakteristik sensor yang dipengaruhi oleh gravitasi bumi, sehingga untuk sumbu pengukuran yang tegak lurus terhadap gravitasi bumi tidak dapat dilakukan pengukuran; Gyroscope dapat mengukur sudut yaw tetapi mengalami drifting karena karakteristik sensor yang membutuhkan perhitungan integral dalam menghitung nilai sudut dari pembacaan kecepatan sudut; laju perubahan sudut yang terjadi adalah $0,064 \%$ untuk sudut pitch, 0,049 $\%$ s pada sudut roll dan $0,046 \%$ pada sudut yaw; (4) Pengukuran sudut yaw dapat dilakukan menggunakan tambahan sensor magnetometer pada complementary filter; (5) Hasil kinerja complementary filter menggunakan gabungan ketiga sensor untuk mengukur sudut kepala pengguna didapatkan dari perhitungan root mean squared error (RMSE) dengan nilai rata-rata $0,364^{\circ}$ pada sumbu putar x (roll), $0,578^{\circ}$ pada poros sumbu y (pitch), dan $0,767^{\circ}$ pada poros sumbu z (yaw).

Saran untuk penelitian ke depan yang dapat dilakukan untuk mengembangkan hasil dari penelitian ini adalah (1) Melakukan perbandingan hasil kinerja algoritma fusion yang lain dengan complementary filter, seperti kalman filter, ataupun Dempster-Shafer serta metode lainnya untuk menghitung sudut gerakan kepala (2) Hasil penelitian ini dapat digunakan sebagai landasan penelitian untuk mengembangankan sistem interaksi antara pengguna cacat tangan dengan smartphone menggunakan gerakan kepala pengguna.

\section{Daftar Pustaka}

[1] Lopez, M. B., Hannuksela, J., Silven, O., Fan, L., (2012), Head-Tracking Virtual 3-D Display for Mobile Devices, IEEE Computer Society Conference on Computer Vision and Pattern Recognition Workshops, 2734.

[2] Kim, J., Park, H., Bruce, J., Rowles, D., Holbrook, J., Nardone, B., Ghovanloo, M., (2016), Assessment of the Tongue-Drive System using a Computer, a Smartphone, and a Powered-Wheelchair by People with Tetraplegia, IEEE Transactions on Neural Systems and Rehabilitation Engineering, 24(1), 68-78, http://doi.org/10.1109/TNSRE.2015. 2405072.

[3] Naizhong, Z., Jing, W., Jun, W., (2015), Hand-Free Head Mouse 
Control Based on Mouth Tracking, (ICCSE), 707-713.

[4] Valeriani, D., \& Matran-Fernandez, A., (2015), Towards a Wearable Device for Controlling a Smartphone with Eye Winks, 7th Computer Science and Electronic Engineering Conference (CEEC15), 41-46, http://doi.org/10.1109/CEEC.2015.7 332697

[5] Lavalle, S. M., Yershova, A., Katsev, M., Antonov, M., (2014), Head tracking for the Oculus Rift, Proceedings - IEEE International Conference on Robotics and Automation, 187-194.
[6] Masters, M., Osborn, L., Thakor, N., (2015), Real-Time Arm Tracking for HMI Applications. IEEE.

[7] Naizhong, Z., Jing, W., Jun, W., (2015), Hand-Free Head Mouse Control Based on Mouth Tracking, (ICCSE), 707-713.

[8] Colton, S., (2007), The Balance Filter a Simple Solution for Integrating Accelerometer and Gyroscope Measurements for a Balancing Platform, http://d1.amobbs.com/bbs_upload78 2111/files_44/ourdev_665531S2JZG 6.pdf, diakses tanggal 12 Februari 2019. 